\title{
Learning about God: Theological education as formation for mission $^{1}$
}

\author{
John Drane
}

John Drane is a trustee of Fresh Expressions and co-chair of the Church of England's Mission Theology Advisory Group, as well as being a fellow of St John's College, Durham. He teaches on the CMS Pioneer Mission Leadership course, training both lay and ordained pioneer ministers.

\section{A new kind of student}

I recently found myself in conversation with a young woman reviewing her first year in theological education. She is typical of a growing number of students: though she has qualifications in another discipline (and a successful career based on them), now in her mid30 s she has a sense of calling to some form of Christian ministry - not necessarily full-time ordained ministry in the traditional mode, though as she works through her vocation she is open to wherever the Spirit might lead her. In a previous era she might well have pursued this calling through volunteering in her local church rather than studying for a degree in theology, but changing cultural norms mean that there are fewer opportunities for such informal ministry and - like many of her age - she is frustrated by a perceived lack of connection between the concerns of the church and the issues with which she finds herself wrestling in everyday life. She wants to be part of an environment where hard questions are acknowledged and addressed in a context of faithful discipleship and has an intense desire to share the gospel with others in her neighbourhood, while being embraced 
and supported by a community that will facilitate her own spiritual growth and maturity. In theory, she regards all that as central to the calling of the local church, but in practice it is not happening, so by way of addressing these questions for herself she decided to sign up for a theology course, anticipating that this would be a safe space in which to work on answers to some of the tough questions of faith, while finding personal support and encouragement.

In recent years I must have had hundreds of similar conversations with students in many different countries and from diverse denominational backgrounds, usually engendered by the inability of local churches to engage with the sort of challenging questions that are inevitable in a world where cultural change is both rapid and unpredictable. For struggling congregations, anyone who asks questions is likely to be perceived as a troublemaker, if not a heretic, and will easily find themselves marginalized by the larger group. In many churches, having too much enthusiasm is seen as a dangerous thing, and it is often easier to withdraw than to stay and argue. Some give up on the church altogether, ${ }^{2}$ while others pursue theology courses in the hope that focused study might help them to a deeper understanding not only of faith but of themselves and their own vocation. The case studies included in the Church of England's ground-breaking Missionshaped Church report ${ }^{3}$ highlighted the ways in which individuals like this could make a difference, and one of the unexpected outcomes has been the embedding of fresh expressions of church within the traditional institutions and the formal recognition of pioneer ministers, both lay and ordained. ${ }^{4}$ Research into this new missional movement has revealed that more women than men have been instrumental in forming new faith communities, ${ }^{5}$ and that matches anecdotal evidence from my own experience, that women are more likely than men to study theology to explore their own existential questions about life and faith with a view to their greater missional effectiveness.

\section{Challenges to the system}

My conversation partner is typical of many such individuals. As we discussed her first year of study, two things stood out. On the one 
hand, she expressed significant frustration with the classes that she had attended. Some of that was predictable: things like students showing up for seminars without having done adequate preparation and often insisting on their own agendas, along with issues related to timetables and sub-standard meeting spaces. But she also commented that she would probably have learned more if she had been given a list of useful resources and left to explore them by herself rather than attending classes which, at best, conveyed similar information in a less interesting way. She confided that if she had known where to find all this before enrolling, she might never have signed up for the course but would have explored it in her own time. It is only a focused and highly motivated student who could plausibly make such a claim. Nevertheless, there is a serious point here, especially if we extend the sources of information to include videos and websites as well as books. She pointed out that some theology professors have more material online than they could ever deliver in a whole year's worth of teaching in their own institutions, all of it available either for nothing or for significantly less than the overall costs of being a full-time student. This is not the place to explore that further, except to note that there is no shortage of available material and much of it is of higher quality, and more engaging, than most of us can ever hope to deliver in the classroom, not to mention diversity of theological viewpoints. ${ }^{6}$

Her second observation was that she had expected the whole experience to be 'much more Christian' than it turned out to be. Broadbrush critiques like this regularly appear in student evaluations, but these comments were not from someone hiding behind the anonymity of a questionnaire: this was an intelligent woman sitting with me over a cup of coffee and pouring out her heart with a remarkable openness and vulnerability considering the potential power imbalance between us. ${ }^{7}$ She was more regretful than angry, and her expectation of something 'more Christian' was in no way related to the study of other world faiths, nor was it driven by any theological agenda. It was rather an intuitive reflection on the ethos of the place, in which she had anticipated there would be a more intentionally spiritual dimension than appeared to be the case. The easy response would have been to 
remind her that the institution in question has regular times of formal worship, not to mention informal prayer groups and the likes - in all of which she had been fully engaged. I could also have pointed out that many educators would argue that formation is not their primary responsibility, but is something that (if it is important at all) ought to be happening elsewhere, whether through local congregations or at a regional or national level. I could even have offered her a carefully argued case in favour of both these things. We should be able to assume that the cultivation of habits of devotion will be an indispensable component of theological education, indeed I would wish to argue for more of it than typically occurs already. Likewise in relation to the role of the church: if spiritual formation is not central to the life of a congregation, I might be asking in what sense it could claim to be a fully ecclesial community. I could also have explained to her how the fast-changing missional and educational context is threatening the wellbeing of many faculty members, who find themselves so overburdened with administration that they have little time to think creatively about their own vocation as teachers, and when they do many are out of their depth in knowing what to do about it. In that respect, theology professors are no different than many other professionals, for whom things are changing at a pace that no-one could have foreseen and to which very few are able to adapt successfully.

We are living through a time of unprecedented cultural upheaval in which the inherited patterns of education for Christian ministry were determined by a Christendom that no longer exists, and the emerging cultural ethos is not only clouded with uncertainty but is impossible to predict, as what happens next is not necessarily contingent on anything that has gone before. Different denominational traditions have their own unique challenges, but two realities are inescapable. The inherited model assumed that church leaders would be pastors of congregations with skills in teaching and pastoral care. As engagement in traditional church life declines, and the average person has no interest in any form of faith, the need now is clearly for individuals who can connect with the wider population and communicate Christian faith in new ways appropriate to the questions that people have in a time characterized by 
fear and uncertainty. There is widespread recognition that the people who can most easily do that are those with the apostolic charism typified by my conversation partner, who (though she does not use the term) will be (actually is already, though without formal recognition) a bi-vocational minister. Such people tend to come into our classes with rather different expectations than those of previous generations, looking not only for information but for the spiritual wisdom to know what to do with it. It is all too easy to indulge ourselves in defence of the status quo, but the way in which we now access information, not to mention the multiple ways in which the wider society is open to exploring spirituality, invites us to ask more radical questions of our own expectations and practices.

Historically, spiritual growth was addressed through a monastic model of community, in which academic learning and personal formation were part of a single residential experience. Some traditions still value that, though more often the commodification of education and the privatization of spirituality, along with financial constraints, have conspired to separate the two. Post-Reformation theological educators have often struggled to maintain an appropriate balance between academic learning and spiritual formation ${ }^{8}$ and while it is easy to lament what has been lost, turning the clock back is not an option. The reality is that the only point at which many students (ordinands as well as others) are fully engaged is going to be in formal class meetings: for more than are willing to admit it, this actually becomes their de facto 'church' as students. So how might information and formation be combined as part of a holistic educational experience in such a way that it results in personal transformation? There will be many ways of answering that question, but in what remains of this article I will share a particular case study from my work with Fuller Seminary over the last twenty years or so.

\section{Changing the paradigm: a case study in mission education and creative formation}

I first thought about that question when my wife was studying at the Graduate Theological Union in Berkeley, where her mentor 
was the legendary Douglas Adams, a Hebrew scholar whose main interest was in theology and the arts. ${ }^{9}$ At the time, some professors at Fuller Seminary were beginning to develop what became the Brehm Center for Worship, Theology and the Arts, and in light of my wife's interests they invited us both to join them in their explorations. ${ }^{10} \mathrm{My}$ personal starting point was in the interface of faith and culture, and we combined that with her interests in the arts to develop a course that might serve as an introduction to missional theology that would have theological integrity and academic rigour in disciplines as diverse as cultural and media studies, missiology, church history, biblical studies, psychology and practical theology - while at the same time being spiritually formative. We were encouraged to dream dreams, with no expectations of what might emerge and what did emerge was a course based not on a traditional theological paradigm, but on something familiar to the everyday experience of people everywhere: the image of a house (or home) around which everything else would be arranged. It could be our own house, or the students' houses, or indeed God's house, and using this model we would inhabit each of the rooms in turn as a way of exploring key themes in contemporary theological reflection within a formative environment. We knew that to create a safe space combining cognitive and affective learning, time would be of the essence - lots of it. We settled for four-hour sessions which could fit into a morning ( $8 \mathrm{am}-12$ noon), an afternoon (1-5pm) or evening (6-10pm), which over ten weeks (or ten days of intensive classes) gives 40 hours of class time. Each room includes the same elements, not in any fixed order but all starting from an inductive, interactive and reflective perspective born of the participants' own experience. Presentations (either short ten minutes in class or longer videos online) sit alongside activities designed to explore affective aspects of the topics. These might include music, song, movement, drawing, collage, ritual, or mime - though not all in the same session! Then there will always be at least one or two breaks for coffee and informal conversations.

Unsurprisingly, the journey begins in the porch, where we unpack the baggage we bring with us and the expectations we have, at this stage focusing on students' experience of the wider culture rather 
than personal baggage, and then set it all in the context of the bigger picture of cultural change, exploring understandings of modernity, post-modernity and so on - while always asking where God might be found in the chaos (the missio Dei). Numbers will always determine how much time is available but giving everyone as much of a voice as they need is important for establishing the sort of open ethos that can ultimately enable positive formative experiences.

After the porch, the journey could obviously go in many different directions, though the order of rooms has been carefully chosen so as to enable a growing sense of safety in the community of the class. Typically the living room is next, which we describe as a place where we tell stories. This time it will be more specifically our own faith stories, which easily and naturally connects with themes of narrative theology and creative ways to use the Bible, engaging with classic hermeneutical approaches as well as models for working with youth, or older people, or whatever contexts might be relevant to the members of the group. After that we usually visit the garden with themes of creativity, beauty and imagination, starting with God as Creator, the nature of the imago Dei in relation to humans as co-creators, combined with practical explorations of the place of the arts in ministry and mission in relation to the heritage of whatever denominational streams might be represented. Other questions might focus on who we could meet in natural environments (pagans and other spiritual searchers, perhaps), with some attention then to environmental theology as well as practical missional outcomes such as Forest Church - and often some involvement with living plants as a reflection on spiritual growth.

Back inside, the basement (loft or garage, as culturally appropriate) will be next, sorting through the debris from the past and deciding what to keep, what to discard, and what to recycle or reimagine so as to be serviceable in a new context. This might involve our own journeys of faith, maybe an introduction to stages of faith, as well as inherited traditions from our various ecclesial contexts and their usefulness or otherwise in new contexts - often explored through play with some of the discarded stuff to facilitate engagement with topics such as communication in different historical eras. Next comes the kitchen, where we might expand on some of these issues, as the place 
where community happens - a natural introduction to potentially controversial questions around who does actually belong in the community of faith. This frequently involves in-depth examination of some New Testament texts, around the question of 'How much faith is enough?' using the example of Jesus' own disciples. Other themes that can easily feature here would be the relationship between personality type and spirituality, and between discipleship as action and theology as reflection, inspired by insights from liberation theology.

By now we are halfway through the course, and students generally recognize that it is a safe space where their vulnerability will be respected. So we head to the bedroom, themes of which hardly need to be spelled out but include the whole spectrum of relationships in today's homes. Participants' own stories are especially important here as there will inevitably be many sensitivities and lifestyles that some students might find challenging. It takes a good deal of skill to navigate all that in today's American context, though historical exploration of family structures can help, along with reminders that different cultures have different relational norms. Pastoral and evangelistic needs and opportunities might be explored in relation to narratives that are already among the group, alongside biblical explorations and case studies. Whatever happens in this room, the next one is always the bathroom. Here we can deal with the pain of the morning after the night before, addressing issues of alienation and embarrassment, invariably focused around the therapeutic potential of mask-making, which not only reflects themes like revealing, washing, forgiveness or cleansing, but also creates a space for having messy fun in the process as well as rediscovering practices of the ancient church that are often lost in some traditions (things like confession, anointing, blessing, and so on). ${ }^{11}$ Finally, a liturgy of reconciliation between women and men which can be both scary and liberating, not only for the words but for the format of sitting on the floor with women encircling the men, something that invariably moves very quickly from formation to transformation.

The study is the next room, asking how thinking, feeling and doing relate to one another. Here we might work on our own learning styles, ${ }^{12}$ along with research on communication and its implications 
for the church's ministries. But the central theme will be around the question of how to think theologically, exploring the nature of practical theology as an integration of cognitive and affective understandings of God and spirituality. After the study, we head to the construction site, working on what a remodelling and makeover might look like. Here we will reimagine the (literal and metaphorical) space: drawing the plans as we clarify the meaning of key values such as gospel, spirituality, mission, church, and so on; gathering the materials that we need for the rebuilding; dreaming about a renewed community of disciples; and working out how to get from here to there - which will include the nature of diverse ministries, partnerships, giftings and vocation.

The street outside may be the last call. Here we engage with the wider community and explore what it is like to share faith on non-church territory. This might embrace new atheism or new age spiritualities along with the spirituality of sport, set in a context of models from scripture, history, and our own experience while exploring what mission might look like if we start from a theology of creation and incarnation. Of course, the street need not be the end: the possibilities are limitless, constrained only by the imagination. Others that we have included from time to time are the entertainment centre (TV, movies, music, digital media), the wider neighbourhood (shopping, advertising, spirituality of place), the people next door (different people groups, celebrities, disability, social and political allegiances).

\section{Concluding reflections}

This is only one example of a way in which we might think creatively about theological education that will address some of the challenges identified at the beginning of this article, but there are lessons here that have a broader validity and which present challenges to the current pedagogical models. The first is time. Every topic in this course is deeply challenging for somebody, and sometimes for everybody. It takes more than one or two hours to unpack and debrief all that appropriately. Four-hour sessions work well, with unstructured 
informal time always essential, not an optional extra, and not programmed in advance but responsive to the mood of the group. Then there is space. Rooms with desks and lecterns are not only unsuitable but actually prevent appropriate levels of interaction and engagement. The course described here will only work in a studio style space that is big enough for the numbers. ${ }^{13}$ If it can be combined with accessible outdoor space, so much the better. And thirdly, there is what, for want of a better term, might be regarded as attitude. To fulfil an aspiration for a class to be spiritually formative, teachers need to be accompaniers on a journey and not afraid of vulnerability, whether their own or the participants. We need to be prepared to model what we are talking about: there needs to be flexibility rather than working from a fixed script. Astute readers will have noticed, fourthly, a paradigmatic shift here that might be described as prioritizing the social sciences rather than the humanities as the primary model for missional theological discourse - a topic that is worth exploration in its own right, but which would take us well beyond the narrow confines of this article.

The format just described was initially based on hunches and intuitions, and it was only after teaching it for several years that we discovered others were drawn to the same imagery. Walter Wink highlights the importance of 'transformation' as part of the intellectual quest, describing it as

[...] exploring all the sealed and stale rooms of this God's house we call our selves, and offering all we find to the real owner for forgiveness, acceptance, and healing. [...] It is discovering the unjust and violated parts of ourselves [...] a process, not an arriving; we are "transforming," not transformed. But all along the way there are flashes of insight, moments of exquisite beauty, experiences of forgiveness and of being healed, reconciliations and revelations that confirm the rightness of our quest, and whet our appetites for more. ${ }^{14}$

Complementing that from a formative perspective, we discovered Robert Boyd Munger's slim book, My Heart - Christ's Home, which has been a favourite devotional text for American Christians for some 
65 years, in which he imagines taking Christ on a visit to nine different rooms in a home. ${ }^{15}$ Then more recently, Samuel Wells has identified improvisation as an essential disposition for effective ministry, and something that was foundational in the pedagogy that informs the course described here. ${ }^{16}$ When the cognitive, the formational and the pedagogical come together in a single package, maybe there is more in this than ever I imagined to be possible.

\section{Notes}

1 See also John Drane, "Learning for Mission”, Anvil 32/1 (2016), which sets the scene for much that is discussed here. https:// churchmissionsociety.org/resources/learning-mission-john-draneanvil-vol-32-issue-1. (All websites cited here were accessed on July $18^{\text {th }} 2019$.)

2 Philip J. Richter and Leslie J. Francis, Gone But Not Forgotten: Church Leaving and Returning (London: DLT, 1998); Philip J. Richter and Leslie J. Francis, Gone for Good? Church-leaving and Returning in the Twenty-first Century (London: Epworth Press, 2007); Alan Jamieson, A Churchless Faith: Faith Journeys Beyond the Churches (London: SPCK, 2002); Steve Aisthorpe, The Invisible Church: Learning from the Experiences of Churchless Christians (Edinburgh: Saint Andrew Press, 2016).

3 Church of England Mission and Public Affairs Council, Missionshaped Church (London: Church House Publishing, 2004).

4 For a succinct account of this, see Angela Shier-Jones, Pioneer Ministry and Fresh Expressions of Church (London: SPCK, 2009). I need to declare an interest here, as a trustee of Fresh Expressions and chair of its Mission-shaped Ministry sub-group, as well as being co-chair of the Church of England's Mission Theology Advisory Group and a recognized teacher for the CMS Pioneer Mission Leadership Training course, which is one of the largest providers of theological education for both lay and ordained pioneers. 
5 George Lings, The Day of Small Things: An Analysis of Fresh Expressions of Church in 21 Dioceses of the Church of England (Sheffield: Church Army, 2016), https://www.churcharmy.org/ Publisher/File.aspx?ID=204265; Encountering The Day of Small Things (Sheffield: Church Army. 2017), https://churcharmy.org/ Publisher/File.aspx?ID=204262

6 The University of Nottingham's Bibledex videos are a good example, with well-known scholars presenting a video on every book of the Bible summarizing key aspects of scholarly thinking: http://www.bibledex.com. More widely, there is something to suit every theological taste, much of it free:

https://www.monergism.com/free-library-online-seminarycourses-lectures https://library.ptsem.edu/resources-for-everyone https://www.thegospelcoalition.org/course/biblical-theology/

\#course-introduction

Others to be paid for:

https://vimeo.com/ondemand/evangelicaltheology

https://vimeo.com/ondemand/contemporarytheology

https://ntwrightonline.org/courses/

http://www.biblicalstudies.org.uk; and many more.

7 Perhaps slightly mitigated by the fact that she was not reflecting on anything that I myself had been involved in teaching!

8 Justo González offers a fascinating account of the reasons for this, as a failed attempt to unite pietist and scholastic interests, in which the scientific and critical approach came to dominate leading to conflicts between fundamentalists and liberals, in which the former 'canonized ignorance' and the latter canonized science resulting in the familiar dichotomy between theology and the life of the church. Justo L. González, The History of Theological Education (Nashville: Abingdon Press, 2015), 115ff.

9 https://www.gtu.edu/library/resources/special-collections/ featured-collections/douglas-g-adams-collection

10 http://www.brehmcenter.com/

11 See Olive Fleming Drane, Making Masks, Healing Persons, and Teaching Practical Theology, available at: 
http://www.spiritualjourneys.org.uk/pdf/

MTAGOlivespaperwebversion.pdf

12 Typically using either VARK: http://vark-learn.com/introductionto-vark/the-vark-modalities/

or Honey and Mumford https://www.talentlens.co.uk/product/

learning-style-questionnaire/?gclid=EAIaIQobChMI17rpp

OG-4wIVmK3tCh0mgwcHEAAYASAAEgLCR_D_BwE

13 Experience suggests that something like 2 square metres of floor space for every person is optimal. The largest number we have ever accommodated at one time was just over sixty participants.

14 Walter Wink, Transforming Bible Study (Nashville: Abingdon Press, 1989), 77.

15 Robert Boyd Munger, My Heart-Christ's Home (Downers Grove, Ill.: InterVarsity Press, rev. ed. 1992, originally 1954).

16 Samuel Wells, Improvisation: The Drama of Christian Ethics (Grand Rapids, Mich.: Baker Academic, 2018; originally Brazos Press, 2004). 